\title{
THE EFFORT TO ACHIEVE EQUALITY WITH THE HELP OF THE REVERSAL OF THE BURDEN OF PROOF IN ANTI-DISCRIMINATION LITIGATION
}

\author{
Monika Forejtová ${ }^{1}$
}

\section{Faculty of Law, University of West Bohemia in Pilsen, Czech Republic email: forejtov@kup.zcu.cz}

FOREJTOVÁ, Monika. The Effort to Achieve Equality with the Help of the Reversal of the Burden Of Proof in Anti-Discrimination Litigation. International and Comparative Law Review, 2013, Vol. 13., No. 1, pp. 137-145.

DOI: 10.1515/iclr-2016-0064.

\begin{abstract}
Application of non-discrimination has a fundamental problem inherent in the fact that the prosecutor has only a very limited possibility to prove violations of the prohibition of discrimination, and much less the motives of the discrimi- $\neg$ nating person, and thus the reason for discrimination. In addition, discrimina $\neg$ tion occurs in the relations, which are characterized by considerable inequalities, when more evidence is on the side of potentially discriminating than on the side of those discriminated. The article offers the analysis and comparison of the US and European approach to the procedural aspects of the anti-discrimination litigation with the special attention given to the special procedural mechanism - the reversal of the burden of proof.
\end{abstract}

Keywords: Anti-discrimination litigation, equality, reversal burden of proof, Unites States, European Union, Czech Republic

"Equality would be heaven if we could attain it." Gerard Queen, professor of Kingston University, Surrey, UK

Application of non-discrimination has a fundamental problem inherent in the fact that the prosecutor has only a very limited possibility to prove violations of the prohibition of discrimination, and much less the motives of the discriminating person, and thus the reason for discrimination. In addition, discrimination occurs in the relations, which are characterized by considerable inequalities, when more evidence is on the side of potentially discriminating than on the side of those discriminated.

For this reason, the U.S. Supreme Court in the 1970s ruled that it is sufficient to prove only "discrimination at first glance - prima facie. In the decisions of the

1 Monika Forejtová is a Senior Lecturer and Head of the Department of Constitutional Law and European Law, Faculty of Law, University of West Bohemia in Pilsen, Czech Republic. Email: forejtov@kup.zcu.cz 
U.S. Supreme Court in case Green v. Mcdonnell Douglas (1973) and in the matter of Texas Dept. Of Community Affaires v. Burdine, 1981, it was noted that the onus of proof of discriminatory behavior is transmitted from the plaintiff to the defendant with the minimum evidence of the obvious case ${ }^{2}$. The factual basis of the dispute was that the candidate for a job who was at the same time a member of an ethnic minority in the United States, had qualifications for the work, and yet she has not been accepted for the position, and this place remained vacant until it was occupied by a person who was not a member of an ethnic minority. This rule of the reversal of the burden of proof was based on the following two premises:

1. Employers are acting rationally, and only they know or can explain the reasons for their decisions

2. The most likely reason why the employer refused a qualified member of a minority on the job vacancy is just his belonging to such a minority.

The new rule about shifting the burden of proof under the US Supreme Court decisions should not be a kind of persuasive burden, but rather an obligation to continue in the proceedings. ${ }^{3}$ In proceedings where there is floating burden of proof, the burden of proof spills over from the side of the plaintiff to the defendant, and vice versa, and this until confirmation or a complete refute of the fact, that, for example, the conduct of the employer in the employment dispute has not even contained a motive that could be considered discriminatory. Thus, the court often examines whether the grounds put forward by the defendant are not only covering the actual reasons for inappropriate treatment of applicants for a job, or employees themselves, thus the reasons for discriminatory behavior. Therefore, it is frequently talked about the actual "discriminatory intent." The first allegation of the existence of discrimination, however, is always on the aggrieved or the plaintiff. What is then, the most frequent way used by the employees to prove their discrimination?

Plaintiffs usually rely on a combination of comparative methods (e.g. a black employee was laid off from his job working for a work misconduct, although an employee of the white skin committing the same misconduct was not fired; or a man looking for work was hired although the female candidate with higher qualifications was not; or a younger employee was promoted, though the older one had more experience, etc.)

The grounds for discriminatory conduct in their mutual combination can be usually presented as follows:

2 OPPENHEIMER D.B., Negligent discrimination, Stanford Law rev. 317, 1987, p. 671

3 St. Mary's Honor Society v. Hicks, 509 U.S. 502 (1992), see SELMI, M.: Proving Intentional Discrimination: The Realtiy of Supreme Court Rhetoric, Georgtown Law Journal 279, 1997

4 Reeves v. Sanderson Plumbing Products, Inc, 530 U.S. 133 (2000) 
a) By proof of fictitious reason (e.g., the employer alleges that the employee has committed a violation of the working discipline and therefore had to be dismissed)

b) By proof suggesting bias against a certain group of people (e.g. a managing employee used, in public or private, allusions to persons of different race, gender, age, education, ethnicity, skin color, sexual orientation, etc.)

c) By proof of discriminatory treatment of other persons (e.g., the employer dismisses at first persons of another ethnicity, or skin color, in the case of his/her difficult economic situation $)^{5}$

d) By proof of the existence of stereotypes on the part of the employer in assessing applicants for the job or the employee (e.g., the implementer of the status of employees committed insults of women or persons of other ethnicity as people reputed to be less able to carry out certain work)

d) By proof of statistical data (in the context of long-term development of case law in the field of discrimination, statistics is often a common proof when the complaining party submits official or their own statistical data about existing or ongoing discriminatory practice of the defendant). ${ }^{6}$

5 C-54/07: Judgment of the Court (second chamber) of 10 July 2008. Centrum voor gelijkheid van kansen en voor racismebestrijding v Firma Feryn NV - statement by the EU Court of Justice: “1) The fact that the employer has publicly declared that they will not accept employees of a particular ethnic or racial origin constitutes direct discrimination in recruitment to employment within the meaning of article 2, par. 2 of Council Directive 2000/43/EC of 29 June 2000, implementing the principle of equal treatment between persons irrespective of racial or ethnic origin, in view of the fact that such declarations can actually dissuade certain aspirants from that to make themselves known, and therefore acts as an obstacle to their access to the labor market. 2) Public statements by which an employer announces that as part of its recruitment policy, the employer will not hire an employee of a certain ethnic or racial origin, is sufficient to create a presumption of the existence of directly discriminatory recruitment policy within the meaning of article 8 (1) of Directive 2000/43. This then is the responsibility of the employer to prove that there has been no breach of the principle of equal treatment. It can do so by proving that the actual recruitment practice of the company does not conform to such declarations. The referring court is to verify that the facts complained of are demonstrated, and determine whether the facts presented to support the statements of the mentioned employer, based on which it did not infringe the principle of equal treatment, are sufficient. 3) Article 15 of Directive 2000/43 requires the system of penalties for infringements of the national provisions adopted in implementation of this directive in the case where there is no specific victim, to be effective, proportionate and dissuasive. "(see Codexis)

6 The judgment of the European Court of human rights, dated February 7, 2006, in complaint No. $57325 / 00$ D. H. and the other against the Czech Republic, where it was in point 38 of the judgment stated that: "the complainants maintain that if a complainant in the case proves an obvious discrimination (for example, by supporting statistics), or it will be revealed by the latest news of international organizations, as it is in this case, the burden of proof is shifted on the defendant government, which must prove that the difference in treatment is justified. In this respect, the complainants refer to the opinion of the Court, according to which, under certain circumstances "it should actually be considered a must have, that the burden of proof lies on the authorities, which must submit a satisfactory and convincing explanation" (Anguelova against Bulgaria, no. 38361/97, sect. 111, ECHR 2002-IV). As a reasonable and objective explanation may not be in their opinion based on insufficient mastery of the Czech language, on the different socio-economic situation and on the consent of the parents of these children, State authorities failed to give such 
Regulation of the European Union is working with the principle according to which the burden of proof moves only with regard to the facts that the plaintiff cannot have reasonable access to, or it cannot have them reasonably at his disposal. Therefore, if the complainant submits a fact suggesting that there has been direct or indirect discrimination, the burden of proof must be moved and the defendant must prove that the breach of the principle of equal treatment did not occur. The difference in treatment as discriminatory behavior is modified also in the meaning of article 14 of the Council of Europe Convention for the protection of human rights and fundamental freedoms ${ }^{7}$, as behavior, which lacks objective and reasonable justification. This means such conduct which does not follow the legitimate purpose and for which there is no reasonable relationship between the means used and objectives pursued.

Council Directive 97/80/EC of 15 December 1997 provides for the burden of proof in cases of discrimination based on sex. This directive was valid until August 14, 2009 and was cancelled by the following EU legislation, which was the European Parliament and Council Directive 2006/54/EC of 5 July 2006 on the implementation of the principle of equal opportunities and equal treatment for men and women in matters of employment and occupation. However, this directive has created room for wider protection of the rights of persons who feel their rights to be affected by a discriminatory expression, for example. of the employer. ${ }^{8}$ This directive is consistent with the Council Directive No. 75/117/EEC, Council Directive No. 76/207/EEC, insofar as discrimination based on gender is concerned, and Directive No. 92/85/EEC and 96/34/EC, which affect the proceedings in the public or private sector. Article 4 (1) of the repealed by Directive No. $97 / 80$ provides for reversed burden of proof. 9 Although the defendant is required to prove the legitimacy and legality of the procedure against the person complaining, but the complaining, aggrieved, party, shall present their evidence as well. The directive states that: "persons who feel harmed by the fact the principle of equal treatment has not been applied to them, shall present in a court or other competent authority, facts from which it can be inferred that there has been direct or indirect discrimination ". 10

an explanation. Even assuming that the inclusion of the complainants to a special school was led by a legitimate aim, but with which they fundamentally disagree, this measure cannot in any way be regarded as proportionate. " (see Codexis) or the EU Court of Justice judgment in case C-415/2010 Meister, (see Codexis)

7 FMZV Communication No. 209/1992 Coll., on negotiation of the Convention on the protection of human rights and fundamental freedoms as amended by Protocols Nos. 3, 5 and 8

8 Council Directive 97/80/EC of 15 December 1997 on the burden of proof in the cases of discrimination based on sex

9 Member States shall take such measures as are necessary, in accordance with their national judicial systems, to ensure that, when persons who consider themselves wronged because the principle of equal treatment has not been applied to them establish, before a court or other competent authority, facts from which it may be presumed that there has been direct or indirect discrimination, it shall be for the respondent to prove that there has been no breach of the principle of equal treatment.

10 Council Directive 97/80/EC of 15 December 1997 on the burden of proof in the cases of 
Rules for application of so called reverse the burden of proof are also laid down in Council Directives 2000/43/EC and 2000/78/EC. In the article 8 of the Council Directive 2000/43/EC, it is stated: "Member States shall take such measures as are necessary, in accordance with their national judicial systems, to ensure that, when persons who consider themselves wronged because the principle of equal treatment has not been applied to them establish, before a court or other competent authority, facts from which it may be presumed that there has been direct or indirect discrimination, it shall be for the respondent to prove that there has been no breach of the principle of equal treatment ${ }^{11}$

This way of the proving shall not apply to criminal proceedings, as well as for the proceedings, where inquisitorial principle applies for the courts or for the decisive authorities. States are obliged to comply with the minimum standards for the protection of weaker parties, they may, however, in their legislation, offer even more protection. ${ }^{12} \mathrm{~A}$ part of this enhanced defense of weaker parties to a dispute is also ensuring access to associations, organizations and other legal entities in judicial proceedings. These bodies, as soon as they prove their legitimate interest on compliance with anti-discrimination law, are accepted into the proceedings (or they even initiate the proceedings themselves) and they usually support the complaining party or they provide it with the necessary legal means (legal advice, funds for the process, etc.) to defend their rights against the employer. It is interesting that on the side of the employers are often big companies, concerns, and/or entities that are in the case of reimbursement for so called non-material damage - financial satisfaction, also able to meet the cost of these auxiliary bodies. ${ }^{13}$

In Czech law, the shifting of the burden of proof is embedded in the provisions of the section 133(a) of the Act No. 99/1963 Coll., Code of Civic Proce-

discrimination based on sex

11 The article 10 of the Council Directive 2000/78/ES is completely identical.

12 The EU Court of Justice judgment in case C- 303/206 Coleman

13 For Example, the European Roma Rights Centre (ERRC) is an organization based in Budapest, which deals with the problems of the Roma and Sinti people in Europe. Its main activities include lobbying and training in the field of human rights. ERRC was founded in 1996 and is managed by the International Commission-http://www.errc.org/ 
dure, as amended by later regulations (hereinafter referred to as CCP). ${ }^{14}$ This regulation implements a significant part of the anti-discrimination legislation. ${ }^{15}$

The Constitutional Court of the Czech Republic in the application for revocation of provisions of section 133 of CCP for its alleged unconstitutionality decided that:

"By the interpretation of the provisions of section 133a (2) of the CPR it cannot be inferred that the person purchasing the services who felt to be racially discriminated against, it is simply sufficient to claim that there was a discriminatory act. This person in court proceedings must not only maintain, but also prove that he/she has not been dealt with in the usual manner, i.e. in the manner which would be to their disadvantage. If this person does not prove the claim, he/she cannot succeed in the proceedings. Furthermore, the person must claim that the disadvantageous treatment was motivated by discrimination on grounds of racial or ethnic origin. $\mathrm{He} / \mathrm{sh}$, however, does not need to prove this motivation, as it is in the case of a proof of a different treatment assumed, however, it is rebuttable, when it is proven otherwise in the evidence.. Indeed, the requirement that the plaintiff had to prove that he/she was discriminated against precisely and exclusively for their racial origin (ethnic) and not due to another reason, is obviously impossible, because to prove motivation (incentive) of the defendant is inherently impossible.

Thus, the appellant's opinion that, in proceedings referred to in the contested provisions of the code of civil procedure "the complaining party has an advantage, since it does not have to prove what should have happened, and why it is a subject of a law suit, while the defendant party has disadvantage because it should demonstrate what did not happen," does not hold. In fact, the burden of proof does not lie solely and exclusively on the side of the defendant. Even the complaining party

14 Provision of section 133 (a) of the CPR. "If the claimant shall state the facts before the court, from which it can be inferred that he/she has been subjected to direct or indirect discrimination from the defendant a) based on sex, racial or ethnic origin, religion, faith, belief, disability, age or sexual orientation in the workplace or other dependent activities including access to them, occupation, business or other self-employed activities, including access to membership in an organization of workers or employers, and membership and activities in professional chambers, $b$ ) on the basis of racial or ethnic origin in the provision of health and social care, in access to education and training, access to public procurement, access to housing, memberships in associations and interest in the sale of goods in a shop, or the provision of services, or (c)) on the basis of sex in the access to goods and services, the defendant is obliged to prove that there was no breach of the principle of equal treatment."

15 Council Directive 2000/43/EC of 29 June 2000, implementing the principle of equal treatment between persons irrespective of racial or ethnic origin, Council Directive 2000/78/EC of 27 November 2000 establishing a general framework for equal treatment in employment and occupation and Council Directive 2004/113/EC of 13 December 2004 implementing the principle of equal treatment between men and women in the access to goods and services and their provision, Council Directive 97/80/EC of 15 December 1997 on the burden of proof in cases of discrimination based on sex, Council Directive 2000/43/EC of 29 June 2000, implementing the principle of equal treatment between persons irrespective of racial or ethnic origin, Council Directive 2004/113/EC of 13 December 2004, implementing the principle of equal treatment between men and women in the access to goods and services and their provision. 
shall bear its burden of evidence and claims. If the complaining party can bear the burden, which must be assessed in each individual case by the court, the defendant is to subsequently prove their claims that the discrimination of racial (ethnic) grounds did not happen. For these reasons, the Constitutional Court came to the conclusion that the provisions of the section $133 a$ (2) is a means proportionate to the achievement of the objective pursued and that, - if applied by the above mentioned constitutionally conforming manner - there shall be fair balance maintained between the requirements of the public interest and the requirements of the protection of individuals fundamental rights. "16

Thus, according to the opinion of Constitutional Court of the Czech Republic, the shifting of the burden of proof does not mean a definitive "condemnation" of the defendant to lose, but a requirement that the defendant in reasonable and convincing arguments explained the non-discriminatory nature of its decision. "The requirement that the complaining party had to prove that the complainant was discriminated against precisely and exclusively for their racial origin (ethnic) and not due to another, is obviously impossible, because to prove motivation (incentive) of the defendant is inherently impossible from very the nature of things." ${ }^{17}$ It is not, therefore, a presumption of guilt. Both the Czech and European legislation work with shared, (also known as shifting or floating burden of proof) burden of proof, because the true transfer of the burden of proof would be inequitable in its result. It would subsequently lead non-proportional effects on the subject the accused of discrimination. In the dispute over discrimination, therefore, a different principle of evidence than in other private-law disputes applies.

The Constitutional Court of the Czech Republic also expressed its opinion on a situation where the ordinary courts had not sufficiently considered the alleged discriminatory act, and stated that Constitutional Court cannot pronounce generally valid conclusion what behavior is discriminatory, because it always depends on the circumstances of the particular case. However, it is necessary general courts properly addressed the alleged objection of a discriminatory act and did not infringe the constitutionally guaranteed right to a fair trial. If the complainant alleges a discriminatory act and this is be documented in a manner from which the discrimination results prima facie, the application of section 133 (a) of the CPR and thus the reversing of the burden of proof, applies. ${ }^{18}$

However, the scope of things, in which the burden of proof passes to the defendant, does not overlap in the whole range with the arrangements contained in the Act. No. 198/2009 Coll., on equal treatment and the legal means of protection against discrimination and on amendments to certain acts (the

16 Points 73,75 of the justification of the finding of the Constitutional Court of the CR Pl. US 37/04 in the matter of the motion for revocation of the law

17 Point 71 of the justification of the finding of the Constitutional Court of the CR Pl. US 37/04 in the matter of the motion for revocation of the law

18 Finding of the Constitutional Court of the CR II. ÚS 1609/08 
Anti-discrimination act). The Anti-discrimination act prohibits discrimination on grounds of race, ethnic origin, nationality, gender, sexual orientation, age, disability, religion, faith and belief in all the areas defined in section 1 (1) of the Anti-discriminatory act. According to the provisions of section 132 (a) however, the burden of proof for may be shifted from the these reasons (with the exception of nationality) only in the workplace or other dependent activity, profession, business or other self-employed activity, membership in the organizations of employees or employers and professional membership and the activities in the professional chambers, and furthermore, on the basis of ethnic origin, the burden of proof is also transferred in the provision of health and social care, in access to education and training, access to public procurement, access to housing, memberships in interest associations and in the sale of the goods in the shop or the provision of services ${ }^{19}$; and on the basis of sex, the burden of proof is transferred in the field of access to goods and services. ${ }^{20}$

Rules of the administrative procedure with regard to proof of discrimination, are listed in the provisions of section 64 of Act No. 150/2002 Coll., Code of Administrative Justice, as amended (hereinafter referred to as "CAJ") and the provisions of the Code of Civil Procedure apply to them mutatis mutandis, that means also provisions of section 133 (a). The Act No. 500/2004, the Administrative Procedure Code as amended, however, does not directly contain provisions relating to the transfer of the burden of proof. If the administrative procedure is controlled by the inquisitorial principle, which, as a rule it is, it is the decision of the administrative body which method of investigation it uses. Administration bodies, when investigating the matter, should therefore use the procedure, which is effectively the same as a institute of shared burden of proof and which will lead to ascertainment of the factual situation of the matter. However, with knowledge of the facts, it could be doubted that the administrative authorities will follow the above mentioned procedure. ${ }^{21}$

On the American continent, where the idea of shifting the burden of proof emerged, some very critical views have been occurring more and more frequently. These opinions are based on skepticism about whether a person of judges themselves, who decide on merit, are involved in so called subconscious discrimination. ${ }^{22}$ The so-called cognitive bias that explains discrimination as a natural part of the human psyche, and in which there are stereotypes that have influence on decision-making without any intention, can negatively affect the

19 Letters $(\mathrm{h})$ to $(\mathrm{j})$ of the provisions of section $1(1)$ of the Anti-discriminatory act complemented by membership in special interest associations, access to public procurement and the area of social welfare, which represents a slice of the area under the letter (f)

20 Letter (j) of the provisions of section 1 (1) of the Anti-discriminatory act

21 ČERMÁK M., KVASNICOVÁ, J.: Několik poznámek k českému antidiskriminačnímu právu, Bulletin advokacie 3/2010, str. 19 (A few notes on Czech anti-discriminatory law, Advocacy Newsletter 3/2010, p. 19

22 LAWRENCE Ch.: The ID, the Ego, The Equal Protection: Reckoning with Unconscious Racism, Stanford Law Rew. 317(2007) 
decision-making process. I believe that, for example, in the matter of D. H. and others v. the Czech Republic, in which the Grand Chamber of the Strasbourg Court finally decided on the existing discriminatory motive in the Czech legislation using the statistics as a decisive argument, such a stereotype about the persistent discrimination against Roma people in the Czech Republic may be considered. This conclusion follows also, inter alia, of all the reports of the Commission at the time when the Czech Republic negotiated its accession to the EU.

Overall, it can be concluded that the fight against discrimination in the form of shifting the burden of proof is now an integral part of the legal systems of countries in Europe, but despite this, the very psychology of discrimination is not completely dealt with. 